\title{
IMPACT OF TAX RELIEF ON PUBLIC FINANCE
}

\author{
Egidijus Bikas ${ }^{1}$, Lina Jurevičiūtè ${ }^{2}$ \\ ${ }^{I}$ Vilniaus University, Lithuania, egidijusvln@gmail.com \\ ${ }^{2}$ Viniaus University, Lithuania, lina.jureviciute@gmail.com
}

\begin{abstract}
Tax reliefs are optional, but a very important element of the taxation system. This element is used for different purposes by a country's government institutions. Tax reliefs are a form of tax expenditure that helps to reduce budget revenues. Tax reliefs influence individual and corporate financial behaviour and can have positive or negative effects on the economic and social factors. In the last few years, expansion of tax relief has attracted worldwide attention because of the fact that, after the global financial crisis, many countries are still suffering from fiscal deficits, and expansion of tax relief has not contributed to solving this problem. Tax reliefs are presupposed to be a fiscal policy tool of significance in various subsystems of public finances. The main aim of this article is to examine the impact of personal income tax reliefs on Lithuanian public finances. To achieve this aim, statistical information was systemized; Monte Carlo method was used to group data by horizontal rows and logical links analysed, which helped to evaluate the influence of tax reliefs on public finances. In the simulations, the Monte Carlo method helped to simulate random samples, which were then examined by adapting the conclusions of the theory of probability and mathematical statistics methods.
\end{abstract}

Keywords: tax reliefs, taxation system, personal income tax

Type of the paper: Empirical study

JEL Classification: H21, H240, H60

\section{Introduction}

Taxes are necessary for the state to carry out its functions. In practice, all taxation systems include tax reliefs, which, in many cases, are essential for defining the scope and structure of taxes by applying certain rules. Tax reliefs are often evaluated as exceptions from tax rules. On the one hand, tax reliefs are an important tax structural element, validated by national laws and international agreements (Tax reliefs, 2014; Valstybinio, 2013), while on the other hand, reliefs are one of the most criticized and controversial elements of the taxation system. Tax reliefs promote businesses, help residents generate more income, and reduce social exclusion, but tax reliefs also increase the cost of tax (a negative impact on public finances). These factors reflect the importance of the tax relief.

Tax reliefs are associated with public and businesses, and have a direct impact on the budget revenue. While analyzing tax reliefs and their impact on public finances, different authors have given different opinions and views, depending on the context in which tax reliefs are evaluated and also taking into account the economic situation. It can be argued that, in all cases, regardless of what the targets are, tax reliefs are related to the expenses in budget or unearned income. So, it is important to accurately and transparently define the goals of tax reliefs, application tools and objectives to assess the potential benefits to the budget. Various methods can be applied for calculating the number of tax reliefs that can be created to save working places, the amount of revenue that will be generated through the use of the benefits expected in the future, and its positive or negative impact on the budget, especially in the long run. It is important to understand that the assessment of tax reliefs should not become the norm and should be considered a short-term promotional tools.

Before making decisions about the application of tax reliefs (when, to whom, which type) the impact of reliefs should be evaluated by the government. Assessing the impact on public finances is not 
enough to assess the loss of earnings; the tax payer's behaviour plays an important role in the assessment.

The goal of the article was to analyze the impact of relief in personal income tax (PIT) on the Lithuanian public finances. Tested hypotheses were:

H1: If the 5 percent PIT rate is increased to 15 percent, the state budget revenues would increase.

$\mathrm{H} 2$ : If the tax-free income limit is reduced, the state budget revenues would increase.

A research was conducted to structure the statistical information by applying the Monte Carlo simulation method.

\section{The concept of tax reliefs}

Taxes are an important source of government revenue, and are a requisite for the state to execute its functions. Essentially, all taxation systems include tax reliefs, which, in many cases, are necessary for defining the scope and structure of the tax. Tax reliefs are often evaluated as exceptions from taxation rules. These exceptions are created in order to implement specific objectives, or to promote or restrict certain behaviours in social or economic policies. Therefore, tax reliefs are an important structural element of taxation that arevalidated by national laws and international agreements (Tax reliefs, 2014; Valstybinio, 2013).Tax reliefs are usually defined in two ways:

- on the one hand, the government suffers a loss of income,

- on the other hand, the tax payers' liabilities are reduced (Tax expenditures, 2010).

Reliefs are one of the most criticized and controversial elements of the taxation system. On the one hand, tax reliefs promote businesses, increase incomes of residents, and reduces social exclusion, but on the other hand, the tax reliefs increase tax expenses (which has a negative impact on public finances). This implies that tax reliefs are diverse and include various elements of the taxation system. Therefore, there is no single concept of tax relief (Bikas et al. 2014). The definitions of tax reliefs vary from evaluating tax incentives as a privilege to categorizing tax relief as tax costs (Table 1).

Table 1. Definitions of tax reliefs

\begin{tabular}{|l|l|}
\hline Author & Definition \\
\hline Vainienė R. (2000) & $\begin{array}{l}\text { Tax relief is a privilege for a particular taxpayer or group of taxpayers. The tax } \\
\text { relief is discriminatory; it applies only to certain, chosen taxpayers' category. }\end{array}$ \\
\hline Bolnick B. (2004) & $\begin{array}{l}\text { Tax relief is - the benefits (determined by the preferential tax rates, exemptions, } \\
\text { etc.). }\end{array}$ \\
\hline $\begin{array}{l}\text { Republic of the Lithuanian } \\
\text { Law on Tax Administration } \\
(2004)\end{array}$ & $\begin{array}{l}\text { For the taxpayer or a group of taxpayers, a law which is established for } \\
\text { exclusive taxation which indicates conditions that are more favourable } \\
\text { compared to normal conditions. }\end{array}$ \\
\hline Swift Z.L. (2006) & $\begin{array}{l}\text { Tax reliefs are tax expenditures created and applied for behavioural changes in } \\
\text { order to encourage certain economic or social objectives. }\end{array}$ \\
\hline Rigsrevisionen's (2007) & $\begin{array}{l}\text { Tax benefits are a set of measures which reduce or postpone taxes for } \\
\text { taxpayers. }\end{array}$ \\
\hline Anderson B. (2008) & $\begin{array}{l}\text { Tax reliefs - indicate some exceptional tax rights, regulatory conditions for a } \\
\text { relatively small group of taxpayers. }\end{array}$ \\
\hline Sudavičius B. (2010) & $\begin{array}{l}\text { Tax reliefs are the exceptional tax conditions that are more favourable } \\
\text { compared to normal conditions, and which provide the right to not pay taxes in } \\
\text { general for a taxpayer. }\end{array}$ \\
\hline Šimonytė I. (2011) & $\begin{array}{l}\text { Tax reliefs (tax exemptions) are budget expenditures that are less transparent } \\
\text { and nearly invisible. }\end{array}$ \\
\hline
\end{tabular}

Having analysed the different definitions of tax reliefs, three essential aspects of tax incentives can be identified: 
- Tax reliefs are a part of the total taxation system.

- They are determined and regulated by law.

- Tax reliefs are expenditures resulting from tax exemptions, which take different forms.

While analyzing tax reliefs and their impact on public finances, different authors have given different opinions and views, depending on the context in which tax reliefs were evaluated and also taking into account the economic situation.

Moreover, tax reliefs are applied in various ways. The reliefs that reduce the tax rate but increase the tax payers' taxable part are most widely used to implement social policy aims. The reliefs aimed at extending the deadline for the tax or eliminating certain tax object are usually used to promote a business or regional economic activity.

The social and economic objectives achieved by applying tax reliefs have a direct impact on the budget revenues, which are known as tax expenses or unearned income. Tax expenses are generally defined as the government's estimated revenue loss resulting from tax reliefs granted to certain classes of taxpayers or activities (Guide to transparency in public finances 2012). In other words, these are a deviation from the standard tax rate.

While summing up the views of different authors, it can be argued that, in all the cases, tax reliefs are related to the budget expenditure or unearned income. So it is important to accurately, transparently and very clearly define the goals of tax reliefs, the application of tools and the object, and assess the potential impact on the budget.

\section{The evaluation methodology of tax reliefs for public finances}

EU Directive 2011/85 / EU (2011) states that each member country should publish information publicly about the impact expenditure of tax has on budget revenues. Taxation system complex analysis is an integral part of a systematic analysis of the tax reliefs and should include different recommendations related to fiscal policy, as it is reflected in the national budget. In this study, the main goal was to define the maximum budget revenue forming a part of the personal income tax (PIT) reliefs that influence budget revenues. In Personal Income Tax Law of The Republic of Lithuania (2002), many cases are defined and distinguished where personal income tax reliefs were applied. All the reliefs can be grouped into three main groups:

1. Non-taxable income (NTI); tax-exempt amount of income, additional NTI amount).

2. Reduced size of the personal income tax (individual by working people).

3. Reliefs for the purchase of certain goods or services (tax overpayment recovery accumulating a retirement pension, life insurance funds, etc.).

Since the tax reliefs are not dual, they cover many areas, and their impact on public finances depends on many factors. The impact evaluation was performed using a simulation method. The objective of assessing the impact of personal income tax reliefs on public finances was to calculate the budget loss (overruns) from the applied incentives for the period 2009-2014. It was modeled on what would be the impact if the reliefs are not applied or are applied to different volume; for this purpose, the lost income method was used. Modeling was used to evaluate one or more than one benefit-related factors. Monte Carlo simulation method was used to evaluate the potential loss of income from PIT reliefs, assuming that not all cases of reliefs were cancelled in order to receive more revenue. The theoretical basis of the Monte Carlo method consists of statistical and probability methods. In computerized simulations by means of Monte Carlo method random volumes are simulated, and then the values obtained are examined by applying probability theory findings and methods of mathematical statistics (Žilinskas, K., 2013). While using the Monte Carlo method to simulate personal income tax for possible disposalof tax reliefs, the following assumptions were used: 
1. Personal income tax is the case counting probability at which the budget revenue would increase if the non-taxable income is cancelled; 15 percent tax on income, which is now subject to a reduced 5 percent income tax rate.

2. The interval that defines the potential extra income without relief limit was determined.

3. Depending on the rate, the revenues received additionally were modelled separately to increase data accuracy.

4. The results were compared with the statistical data and expert estimates.

The goal of analyzing the personal income tax benefits was to estimate the impact of reliefs on the budget. In other words, to calculate the additional amount that would have accrued to the budget if the reliefs were not applied. In order to determine the extent of PIT reliefs, relative variables were calculated, i.e., share of the amount of PIT reliefs in the total amount of PIT revenues received by state budget, in the total budget volume, in GDP.

\section{Personal income tax relief analysis and the impact on public finances}

According to the Ministry of Finance data (2015), the budget losses in 2014 due to application of PIT reliefs amounted to 367 million EUR, which is a 10.1 percent increase over budget losses from 2013. When compared with the economic growth indicators also, it showed that loss due to PIT reliefs increased in 2014 compared with 2013 (Table 2). The increase in the proportion of personal income tax relief amount could have been due to two reasons: as a result of increasing the slab of taxexempted income (from 136 to 166 EUR / month), or an increase in the additional non-taxable income amount for each child to $60 \mathrm{EUR} /$ month.

Table 2. Loss of personal income tax incentives (Source: prepared by the authors based on the data provided by Ministry of Finance LR and Department of Statistics)

\begin{tabular}{|l|c|c|c|}
\hline & $\mathbf{2 0 1 3}$ & $\mathbf{2 0 1 4}$ & Change \\
\hline Loss of personal income tax incentives / GDP & $0.95 \%$ & $1.01 \%$ & $0.06 \%$ \\
\hline Loss of personal income tax incentives / PIT & $7.73 \%$ & $8.02 \%$ & $0.29 \%$ \\
\hline Loss of personal income tax incentives / revenue & $1.20 \%$ & $1.25 \%$ & $0.05 \%$ \\
\hline
\end{tabular}

In Lithuania, employment-related income is taxed at the rate of 15 percent (Lietuvos, 2002). However, an NTI amount is granted to the employees every month, which is 166 EUR per month or EUR 1,922 per year. Families with children get 60 EUR a month for each child, which is an additional NTI (ANTI) amount. It is argued that the NTI and ANTI reduce social isolation and help families with children. The benefits received by the employees as NTI are indicated in Table 3.

Table 3. Budget losses due to PIT incentives (Source: prepared by the authors based on the data provided by the Ministry of Finance LR)

\begin{tabular}{|c|c|c|c|}
\hline Salary (gross) $€$ / month. & NTI & $\begin{array}{c}\text { Effective PIT rate (the ratio of actually } \\
\text { paid PIT rate and wage) (\%) }\end{array}$ & $\begin{array}{c}\text { Paid personal } \\
\text { income tax (EUR) }\end{array}$ \\
\hline 300 & 166 & 6.7 & 20.1 \\
\hline 435 & 128 & 10.6 & 46.0 \\
\hline 580 & 91 & 12.7 & 73.4 \\
\hline 676 & 66 & 13.6 & 91.6 \\
\hline $\begin{array}{c}\text { 928 (of this amount, the NTI } \\
\text { does not apply) }\end{array}$ & 0 & 15.0 & 139.3 \\
\hline
\end{tabular}

NTI, non-taxable income; PIT, personal income tax.

In 2014, under an employment contract, 1.3 million people were employed in Lithuania. By dividing the employees into groups based on salary, we can see that the NTI relief could be used by almost 90 percent of the employees (Table 4). 
Table 4. The number of employees by salary groups (Source: prepared by the authors based on the data provided by State Social Insurance Fund LR)

\begin{tabular}{|c|c|c|c|c|c|c|}
\hline Wage & $\mathbf{2 0 1 0}$ & $\mathbf{2 0 1 1}$ & $\mathbf{2 0 1 2}$ & $\mathbf{2 0 1 3}$ & $\mathbf{2 0 1 4}$ & $\mathbf{2 0 1 4}(\mathbf{\%})$ \\
\hline till 290 & 344 & 349 & 343 & 277 & 262 & $20 \%$ \\
\hline $291-434$ & 272 & 272 & 273 & 281 & 265 & $20 \%$ \\
\hline $435-579$ & 249 & 241 & 249 & 276 & 284 & $22 \%$ \\
\hline $580-652$ & 90 & 93 & 97 & 102 & 103 & $8 \%$ \\
\hline $653-941$ & 157 & 184 & 197 & 220 & 244 & $19 \%$ \\
\hline 942 and more & 73 & 86 & 100 & 118 & 143 & $11 \%$ \\
\hline The total number of employees, thous. of people & 1.186 & 1.225 & 1.259 & 1.274 & 1.301 & $100 \%$ \\
\hline
\end{tabular}

However, when assessing the real impact of the budget on the applicable NTI (the same evaluation and the benefits received by employees), it is appropriate to calculate the average number of employees who did not pay PIT, depending on their income. The analytical results show that the annual PIT reliefs amount to around 300 EUR per year (25 EUR / month.) per person, with the minimum wage of 300 EUR / month (Table 5). For those who receive higher wages, the relief amount decreases. Looking from the public financial position, the amount of NTI tax reliefs in 2014 was about 235 million EUR.

Table 5. The number of employees by salary groups (Source: prepared by the authors based on the data provided by State Social Insurance Fund LR)

\begin{tabular}{|c|c|c|c|c|c|c|}
\hline $\begin{array}{l}\text { Middle } \\
\text { of range }\end{array}$ & $\begin{array}{l}\text { Number of } \\
\text { employees }\end{array}$ & NTI & $\begin{array}{l}\text { Paid } \\
\text { PIT }\end{array}$ & $\begin{array}{l}\text { PIT without } \\
\text { NTI }\end{array}$ & $\begin{array}{l}\text { PIT amount of benefit } \\
\text { per employee } € / \text { year }\end{array}$ & $\begin{array}{l}\text { Annual NTI } \\
\text { incentive, (EUR) }\end{array}$ \\
\hline 300 & 261.973 & 166 & 20 & 45 & 298.8 & 78.277 .607 \\
\hline 362.5 & 265.130 & 147 & 32 & 54 & 264.9 & 70.224 .983 \\
\hline 507 & 283.745 & 110 & 60 & 76 & 197.2 & 55.966 .999 \\
\hline 616 & 103.348 & 81 & 80 & 92 & 146.2 & 15.112 .821 \\
\hline 797 & 243.685 & 34 & 114 & 120 & 61.5 & 14.992 .476 \\
\hline 942 & 142.964 & 0 & 141 & 141 & 0.0 & 0 \\
\hline All in & 1.300 .846 & & 448 & 529 & & 234.574 .886 \\
\hline
\end{tabular}

NTI, non-taxable income; PIT, personal income tax.

In summary, it can be said that although the NTI relief(i.e. 166 EUR / month) seems to be a considerable amount, the real PIT relief is only an additional 25 EUR per month per person employed. It should be noted that about 20 percent of the employees in Lithuania in 2014 received the minimum wage. With an increase in income, the NTI decreased, thus reducing the employee benefits as a result of NTI. Furthermore, the analysis data of the past five years showed that there was a decline in the number of people with the lowest income and an increase in the number of people with higher income. So, the real benefits of NTI were unclear. The state should either increase the size of NTI or it should look for other ways to support the low-income group employees.

According to the PIT law, the PIT can be reduced for residents while purchasing certain goods, paying for studies, or investing in life insurance and third pillar pension funds. The assessment carried out by the Ministry of Finance regarding budget losses due to PIT returns in 2014 is similar to that of 2013.The population declared an expenditure of about 40 million EUR.

In order to have information about the expenditure that reduces taxable income, it is appropriate to analyze the expenditure structure. The analysis showed that in 2013, almost half of the total cost accounted for life insurance premiums (an increase of 8\% in comparison to 2012), about 26 percent expenditure accounted for interest for mortgages, and another 23 percent covered expenditure for studies. There was a significant increase in the number of people insuring their lives. Even though, a relatively small part, contributions to the third pillar pension funds have shown a steady increase over the last 3 years (since 2010) (Table 6). 
Table 6. Expenditure reducing taxable income structure (Source: prepared by the authors based on the data provided by State Tax Inspectorate)

\begin{tabular}{|l|c|c|c|c|c|}
\hline \multirow{2}{*}{ Type of expenditure } & \multicolumn{3}{|c|}{ Expenditure reducing taxable income } & \multirow{2}{*}{$\begin{array}{c}\text { Structural change } \\
\text { 2013 and 2012 (\%) }\end{array}$} \\
\cline { 2 - 5 } & 2010 & 2011 & 2012 & 2013 & \\
\hline Residents paid life insurance premiums & 33.92 & 35.91 & 41.12 & 49.41 & 8.29 \\
\hline $\begin{array}{l}\text { Residents paid interest on loans granted } \\
\text { for housing construction or purchase }\end{array}$ & 40.20 & 39.81 & 35.75 & 25.75 & -10.00 \\
\hline $\begin{array}{l}\text { Residents paid contributions over the } \\
\text { past year for their studies }\end{array}$ & 23.22 & 22.54 & 21.87 & 22.85 & 0.98 \\
\hline Residents covered the loans for studies & 0.09 & 0.13 & 0.20 & 0.32 & 0.12 \\
\hline $\begin{array}{l}\text { Residents paid the premiums to the } \\
\text { additional voluntary pension funds }\end{array}$ & 0.77 & 0.98 & 1.03 & 1.67 & 0.64 \\
\hline
\end{tabular}

To summarize, it can be said that only the PIT benefits related to expenses that reduce the taxable income in terms of public finances can be regarded as very useful. The reasons for this deduction are as follows:

1. Residents are encouraged to accumulate for their future, to invest in life insurance, provide for their own housing, and have access to higher education.

2. Reduces the "shadow" (or declared income).

The PIT loss of 5 percent due to the rate of individual activities income is not very significant. In 2014, it amounted to about 20 million EUR. It should be noted that PIT losses on these preferences almost halved in 2014 as compared to 2013. In 2013, these losses amounted to 53 million EUR (Table 7).

Table 7. PIT taxable individual activities income in 2013 (thous. EUR) (Source: prepared by the authors based on the data provided by State Tax Inspectorate)

\begin{tabular}{|l|c|c|c|c|c|}
\hline & $\begin{array}{c}\text { Taxable } \\
\text { income amount }\end{array}$ & Rate & PIT & PIT 15 \% & Difference \\
\hline $\begin{array}{l}\text { The agriculture-related individual } \\
\text { activities }\end{array}$ & 150.813 & $0 \%$ & 0 & 22621898 & -22621898 \\
\hline $\begin{array}{l}\text { The agriculture-related individual } \\
\text { activities }\end{array}$ & 189.484 & $5 \%$ & 9.474 .209 & 28422627 & -18948418 \\
\hline $\begin{array}{l}\text { Individual activities income received } \\
\text { in the pursuit of other activities }\end{array}$ & 742 & $0 \%$ & 0 & 111.325 & -111.325 \\
\hline $\begin{array}{l}\text { Individual activities income received } \\
\text { in the pursuit of other activities }\end{array}$ & 113.669 & $5 \%$ & 5.683 .462 & 17.050 .386 & -11.366 .924 \\
\hline $\begin{array}{l}\text { Individual activities income received } \\
\text { in the pursuit of other activities }\end{array}$ & 137.242 & $15 \%$ & 20.586 .374 & 20.586 .374 & 0 \\
\hline Individual sports activity income & 33 & $0 \%$ & 0 & 4.994 & -4.994 \\
\hline Individual sports activity income & 10 & $5 \%$ & 515 & 1.546 & -1.031 \\
\hline Individual performing activities & 2.278 & $5 \%$ & 113.895 & 341.686 & -227.791 \\
\hline $\begin{array}{l}\text { Individual Foster Family activities (by } \\
\text { Foster Family Law) }\end{array}$ & 135 & $5 \%$ & 6.745 & 20.236 & -13.490 \\
\hline Total & 594.407 & & 35.865 .201 & 89.161 .072 & -53.295 .871 \\
\hline
\end{tabular}

PIT, personal income tax.

Most of the above-mentioned reliefs are for individuals engaged in agricultural activities.

PIT reliefs in Lithuania are not regarded to only a reduction in tax rate. NTI was evaluated by recalculating the possible budget disposals of the PIT preferences using the Monte Carlo method, which reduced the rate of PIT and personal NTI. For recalculating the amount of PIT that could be 
obtained from the budget in the absence of NTI, first the effective tax rate and PIT base were calculated. PIT base is calculated as the average salary multiplied by the number of employees and the effective tax rate. The simulation showed that the increase of rate (while reducing NTI at the same time) would result in receiving PIT in the range of 806-892 million EUR in the budget for 2014. It is important to note that the Monte Carlo simulation shows that by eliminating the PIT benefit, the probability of receiving such PIT revenue could be 71 percent. Thus, the reliefs' destruction of the wage market would affect 29 percent (in case of failure). By evaluating the probability and deducting PIT base, it can be said that the budget losses from NTI were between 160 and 221 million EUR. It is 14-75 million EUR less than the estimated loss when calculated by applying income method. Influence of elimination of NTI on income is shown in Fig.1. The second hypothesis was confirmed.

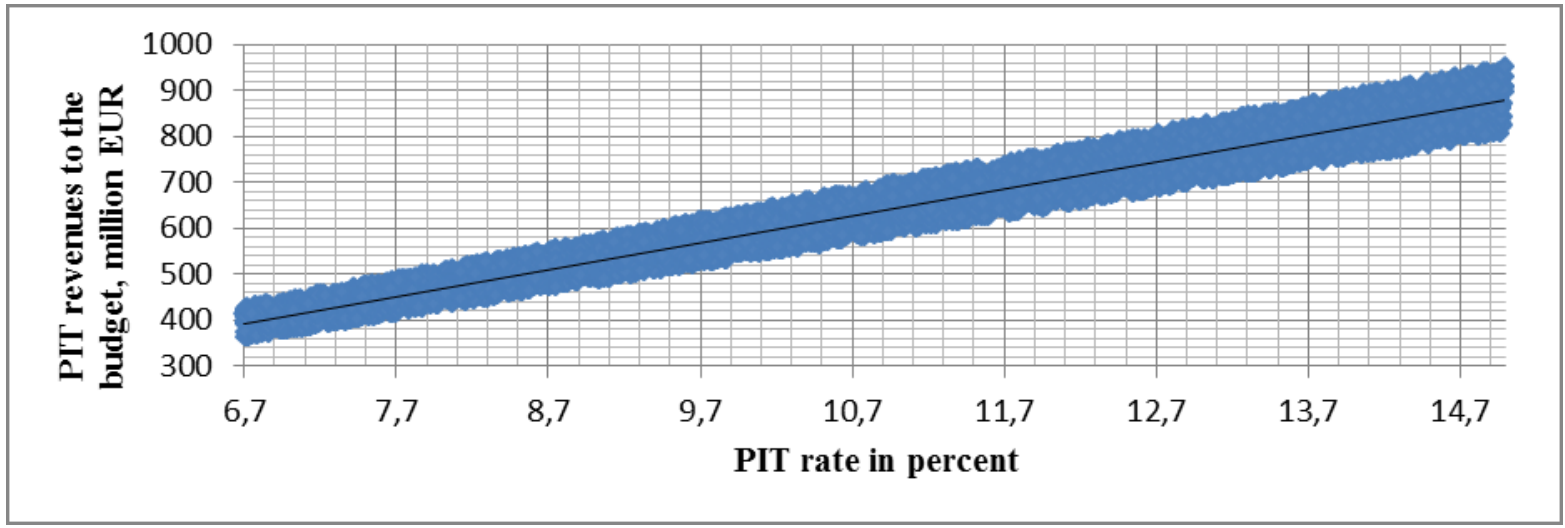

Fig. 1. PIT revenues without NTI (Monte Carlo simulation method, source: prepared by the authors)

Instead of a reduced 5 percent PIT rate, the 15 percent rate was applied in the Monte Carlo method to find the probability of 74 percent, which indicated that the elimination of the preferential tariff is likely to be 26 percent less than the estimated loss of income method. Collecting PIT income (applying 5 percent PIT rate), the revenue from PIT in 2014 could be from 38 to 46 million EUR. This was 7-15 million EUR less than the loss calculated by applying the income method. Monte Carlo simulation results are presented in Fig. 2.

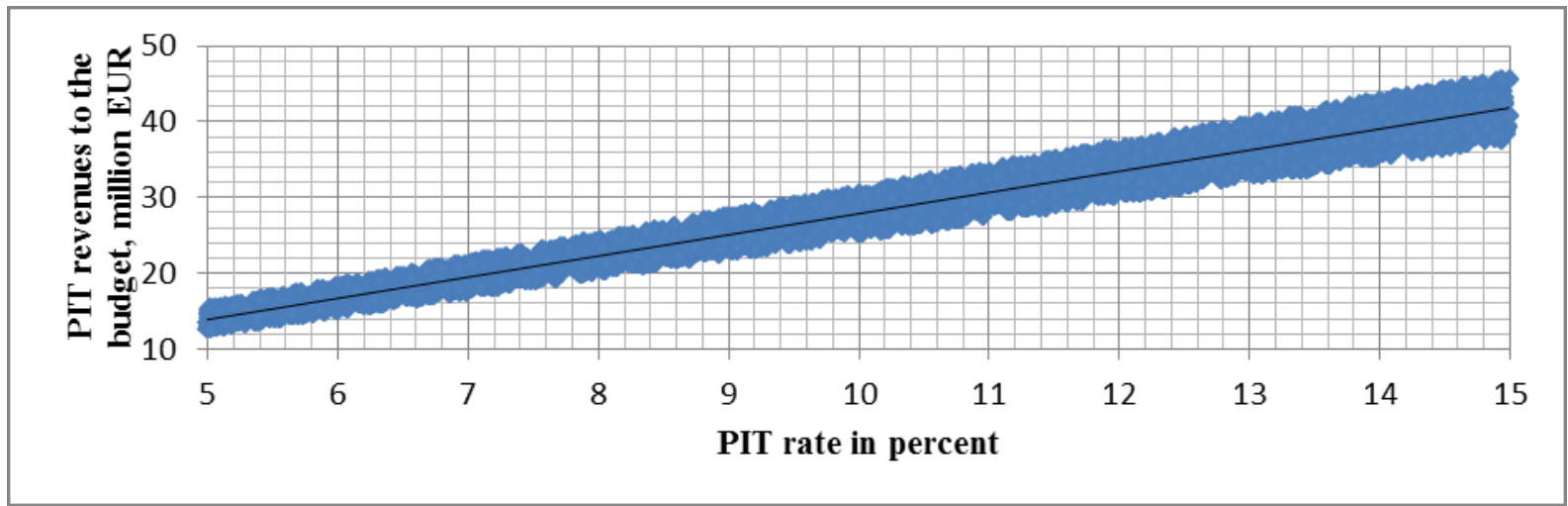

Fig. 2. PIT revenues depending on PIT rate (Monte Carlo simulation method, source: prepared by the authors)

The probability of collecting more revenue was 74 percent. It was assumed that cancelled incentives associated with 5 percent rate would provide 28-34 million EUR higher income to the budget. It was 19-25 million EUR less than the loss calculated by applying the income method (53 million EUR). The first hypothesis was confirmed.

Also, the amount of additional revenue in 2014 budget that would result from the standard PIT rate of 
taxation of goods and services that are non-taxable was calculated. The possible additional PIT income and the cancellation of tax-free income incentives would generate21-22 million EUR. Simulations have shown that the probability that it would increase the revenue was $98 \%$.

The assumption was that the budget of the cancelled incentives related to 0 percent rate could increase from approximately 20.6 to 21.6 million EUR (Fig. 3).

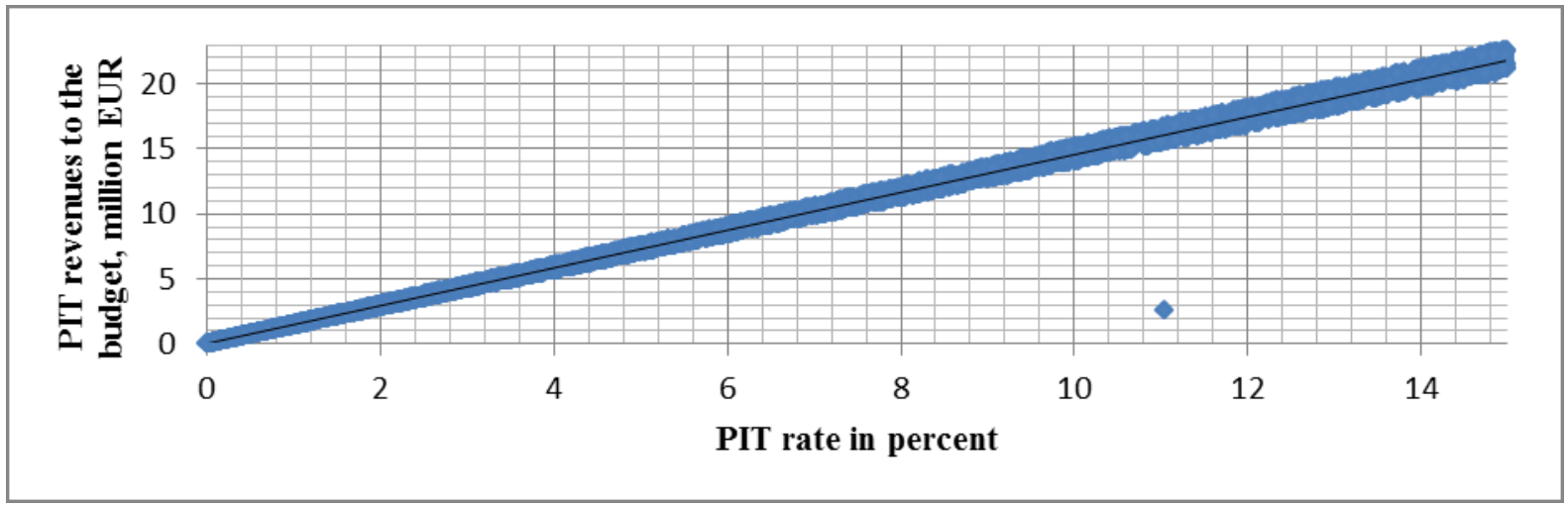

Fig. 3. Additional PIT revenues cancelled of 0 percent incentive (Monte Carlo simulation method, source: prepared by the authors)

Thus, state budget can loose 209- 277 million EUR of PIT revenues because of tax reliefs. Using the Monte Carlo method, which helps to assess probabilities (changes in the labour market), it was estimated that the loss of revenues from PIT would be from 51 to 119 million EUR; significantly lower than the loss calculated using the income method (328 million EUR).

\section{Conclusions}

NTI amount results in income tax progressivity, but the real benefits are questionable. Income growth trends suggest that in the year 2014, out of the total employed population, only one-fifth of the workers were able to get reliefs while the remaining employees did not apply for NTI. Public finance, the NTI and ANTI make the largest share (67 percent) of the total PIT losses because of reliefs.

The biggest budget losses are calculated on NTI (235 million EUR).

The expenditure reduces the taxable income in order to promote fiscal transparency, as residents are interested to declare their income. It also encourages residents to save for their retirement, to insure life, to seek higher education and to have mortgages. The loss of cost reducing taxable income is 5.5 percent of PIT due to the losses in reliefs.

PIT losses due to 5 percent rate from individual activity income in 2013 could be between 20 and 53 million EUR. The largest losses result from the reduced PIT rate applicable for agricultural activities, involving individual activities and other activities.

Through the Monte Carlo method for the evaluation of possible changes in the labour market, it was estimated that abolishing the PIT reliefs would bring in an additional 209-277 million EUR to the budget in the year 2014 .

Due to the reduced 5 percent rate reliefs, the loss of revenue in 2015 could be around 53 million EUR, and the personal income on non-taxable goods and services would be about 40 million EUR.

\section{References}

Anderson, B. (2008). PowerPoint presentation at the Assian Senior Budget Officials meeting, 10-11 January 2008, Bangkok, Thailand. [Accessed 8.11.2015]. Available from Internet 


\section{http://www.oecd.org/gov/budgeting/39944419.pdf}

Bikas, E. ir kt. (2014). Evaluation of social, economic and fiscal impact on intensives of personal taxation in Lithuania. Journal of Securuty and Sustainability Issues 2014. Selected papers. Volume 4(1):79-95.

Bolnick, B. (2004). Effectiveness and Economic Impact of Tax Incentives in the SADC Region. Technical Report. [Accessed 20.11.2014]. Available from Internet: http://pdf.usaid.gov/pdf_docs/PNACY929.pdf

Council directive 2011/85/EU of 8 November 2011 Requirements for budgetary frameworks. [Accessed 25.10.2014]. Available from Internet: https://www.vtv.fi/files/4567/EU_Budgetary_Framework_Directive.pdf

Guide to transparency in public finances. Looking beyond the core budget (2012). [Accessed 10.06.2014]. Available from Internet: http://internationalbudget.org/wp-content/uploads/Looking-Beyond-the-Budget-2-TaxExpenditures.pdf

Lietuvos Respublikos mokesčių administravimo įstatymas Nr. IX-2112. Valstybės žinios, 2004, Nr. 63-2243.

Lietuvos Respublikos gyventojų pajamų mokesčio įstatymas. Nr. IX-1007. Valstybės žinios, 2002, Nr. 73-3085.

Rigsrevisionen's. Report to the Public Accounts Commitee on transparency of tax expenditures (tax exemptions, allowances, etc.) (2007). Budget process and prepatory legislative work. [Accessed 28.10.2014]. Available from Internet: http://uk.rigsrevisionen.dk/media/1390340/01_2007 transp_of_tax_oct_2009.pdf

Sudavičius, B. (2010). Mokesčiu lengvatos Lietuvos mokesčiu teisès kontekste. Teisè 76, p.100-114. [Accessed 25.10.2014]. Available from Internet: http://www.vu.lt/leidyba//dokumentai/zurnalai/TeisAe/TeisAe\%202010\%2076\%20tomas/100-114.

Swift, Z. L., (2006), Managing the Effects of Tax Expenditures on National Budgets. The World Bank. Nr. WPS3927. [Accessed 29.10.2014]. Available from Internet: http://elibrary.worldbank.org/doi/pdf/10.1596/1813$\underline{9450-3927}$

Šimonyte, I. (2011). Bus peržiūrimos mokesčių lengvatos. Mokesčių žinios. Nr. 39 (887).

Tax Expenditures in OECD Countries (2010), OECD. DOI: 10.1787/9789264076907-en.

Tax reliefs (2014) Report by the Comptroller and Auditor. UK: General National Audit Office. HC 1256 Session 2013-14.[Accessed 25.10.2014]. Available from Internet: http://www.nao.org.uk/wpcontent/uploads/2014/03/Tax-reliefs-summary.pdf

Valstybinio audito ataskaita: Mokesčiu lengvatos. Vilnius: Lietuvos Respublikos valstybès kontrolè, $2013 \mathrm{~m}$. 2013 m. birželio 7 d. Nr. VA-P-60-3-7.

Vainienè, R., (2000) Mokesčiu lengvatos: ištakos, ribos ir pasekmès. - Mokesčių žinios 14(165), 5

Žilinskas, K., (2013) Statistinis modeliavimas ir analize. Šiaulių universitetas informatikos katedra. Powerpoint prezentacija. [Accessed 14.11.2015]. Available from Internet: http://ik.su.lt/ kestzil/SMA/SM\&A 1.pdf 